УДК 371.311

DOI: $10.35619 /$ iiu.v1i10.175

\author{
Сергсєва Наталія \\ кандидат педагогічних наук, \\ старший науковий співробітник \\ Інституту проблем виховання НАПНУ, \\ м. Київ, Україна \\ ORCID: 0000-0001-8153-2911, \\ e-mail: sergeeva.nataliya.v@gmail.com
}

\title{
ПСИХОЛОГО-ПЕДАГОГІЧНІ МЕТОДИ ДОСЛІДЖЕННЯ МІЖОСОБИСТІСНИХ ВІДНОСИН ДІТЕЙ ІЗ СІМЕЙ ВИМУШЕНИХ ПЕРЕСЕЛЕНЦІВ
}

\begin{abstract}
Анотація. Стаття присвячена підготовці соціальних педагогів до дослідження міжособистісних відносини дітей із сімей вимушених переселенців. Розкрито сутність та зміст понятійного апарата. Охарактеризовано поняття «міжособистісні відносини». Зазначено, що міжособистісні відносини охоплюють широке коло явищ, де головним регулятором неповторності міжособистісних стосунків $є$ привабливість однієї людини для іншої. Описано класифікацію міжособистісних відносин, що спирається на кілька критеріїв: глибину стосунків, вибірковість щодо партнерів, функції стосунків. Проаналізовано психологічні детермінанти формування міжособистісних відносин, характеристики та соціально-психологічні особливості спілкування дітей із сімей вимушених переселенців, кризові періоди підліткового віку. Метою статті є підготовка соціальних педагогів до дослідження міжособистісних відносин дітей із сімей вимушених переселенців, розкриття особливостей їх діагностики. Визначено основні завдання та методи діагностики міжособистісних відносин особистості. Зазначено, що у дослідженні міжособистісних відносин найбільш важливим показником $є$ рівень конфліктності та іiі специфічні риси. Охарактеризовано адаптивні механізми підліткового віку. Розкрито основні характеристики та соціально-психологічні особливості кризи підліткового віку.

Вивчення та аналіз літератури 3 проблеми дослідження дозволили дослідити психолого-педагогічні методи діагностики міжособистісних відносин 3 позиції соціально-педагогічної науки.

Ключові слова: вимушені переселенці, криза підліткового віку, міжособистісні відносини, підлітки, психолого-педагогічні методи, спілкування.
\end{abstract}

Постановка проблеми. Сучасний стан розвитку суспільства характеризується динамічними змінами в освітній сфері, гуманізацією виховного процесу, посиленням уваги до підростаючого покоління. Українське суспільство сьогодні переживає черговий кризовий період, пов'язаний з багатьма чинниками. Найбільш руйнуючою обставиною сьогодення є збройний конфлікт на сході держави. Слід враховувати, що внутрішньо переміщені особи можуть відчувати ізольованість і несприйняття зі сторони приймаючої громади. Це $\epsilon$ перешкодою для побудови нових стосунків, працевлаштування за місцем переселення. Більшості 3 них важко чи неможливо влаштуватися на новому місці відповідно до звичних умов життя та соціального статусу. Часто їм доводиться змінювати життєві орієнтири та набувати нових як професійних, так і соціальних навичок.

Особливо стресовими і травматичними події стали саме для дітей, які змушені були змінити місце проживання і навчання. Ці чинники впливають на дитину в період iii розвитку, у такий спосіб порушуючи усталені процеси формування і становлення особистості. Діти $є$ більш вразливими та чутливими до впливу несприятливих чинників оточуючого середовища у порівнянні з дорослими. Пережитий травматичний 
досвід впливає на когнітивні процеси, особливості поведінки, міжособистісні відносини, самооцінку і загалом на світогляд. Такі травмуючі обставини залишають дитину без стабільного, безпечного та підтримуючого оточення, яке $є$ необхідним для iii нормального розвитку та становлення; батьки, самі переживаючи тяжкий стрес та кризу ідентичності, не завжди здатні виконувати звичні сімейні ролі, що унеможливлює допомогу своїм дітям. Виникає ситуація, що диктує необхідність соціально-педагогічного супроводу, який виступає одним з механізмів стимулювання процесу соціалізації, соціального розвитку і соціального виховання.

Підлітки, незадоволені відносинами у сім'ї, схильні до спілкування з однолітками, де задовольняється більша частина їх інтересів. У таких умовах для кожного підлітка виникає неповторна ситуація спілкування та міжособистісних відносин і кожний займає серед однолітків певне положення. Підлітки по-різному сприймають відносини 3 однолітками: одні не усвідомлюють свого реального положення та ідеалізують свої відносини з оточуючими, інші, навпаки, перебільшують ситуацію і часто переносять невдачі з однієї сфери відносин у іншу.

Аналіз останніх досліджень 3 проблеми. Під взаємовідносинами розуміють особистісне важливе, образне та інтелектуальне відображення людьми один одного, що являє собою їх внутрішній стан. Саме спілкування є тим процесом, в якому цей стан актуалізується і проявляється; це така поведінка, в процесі якої розвиваються, проявляються та формуються міжособистісні відносини.

Міжособистісні відносини $\epsilon$ найбільш значущими для особистості. Неофіційність, особиста значущість, емоційна насиченість становлять основу для впливу стосунків на особистість.

Міжособистісні відносини - сукупність об’єктивних зв'язків та взаємодій між особами, які належать до певної групи. Характерною ознакою міжособистісних стосунків є їх емоційне забарвлення (Трофімов та ін, 1999, с.98).

Отже ми можемо визначити їх як взаємини, що формуються в процесі безпосередньої взаємодії, мають неформальний характер і емоційно забарвлену та значущу оцінку партнерів зі спілкування.

Міжособистісні відносини охоплюють широке коло явищ, але головним регулятором неповторності міжособистісних стосунків є привабливість однієї людини для іншої. Тому стан задоволеності-незадоволеності виступає основним критерієм оцінки таких стосунків.

Процес міжособистісних відносин тісно пов'язаний з емоційною сферою. Почуття, співчуття та співпереживання допомагають адекватно розуміти інших людей. Уміння сприйняти почуття іншої людини як власні, здатність до емоційного відгуку необхідний компонент спілкування та специфічний засіб пізнання людини людиною. Цей феномен має назву емпатія.

Зокрема I. Юсупов зазначає, що емпатійні якості розвиваються тим інтенсивніше, чим багатшими й різноманітнішими є уявлення про інших людей. Розуміння інших пов'язане з розумінням самого себе (Юсупов, 1991, с. 37).

Розвиток емпатії залежить не стільки від кола взаємодії з іншими людьми, скільки від суб'єктивної значущості цих осіб для особистості, тобто зумовлений кількістю осіб, яких вона по-справжньому цінує. Обмеженість кола осіб, яким схильна співчувати людина, не тільки блокує емоційну чутливість, а й в окремих випадках вона може переходити в жорстокість.

Метою статті $\epsilon$ підготовка соціальних педагогів до дослідження міжособистісних відносин дітей із сімей вимушених переселенців, розкриття особливостей їх діагностики.

Виклад основного матеріалу дослідження. Оскільки об'єктом діагностики є особистісна активність підлітка, то $€$ необхідність коротко розкрити особливості цього віку. 
Підлітковий вік - період активного формування іiі фізичної, інтелектуальної, соціальної та духовної сфер. У підлітків помітні новоутворення, а саме: підвищується розумова активність, змінюються погляди на особистісні цінності, починається новий та складніший етап стосунків 3 дорослими, однолітками. Підліток уже по-іншому оцінює себе в колективі, свої успіхи в навчанні, праці. Одні підлітки свідомо регулюють свою поведінку, виявляють ініціативу та наполегливість у діях та вчинках, інші ж навпаки прагнуть довести свою дорослість, але в результаті наслідують гірше у поведінці (Енциклопедія освіти, 2008, с. 677).

Головна потреба мати гарні взаємини та спільні інтереси. Часто знаходять друзів за принципом подібності. Тому важливого значення у підлітковому віці набуває спілкування. Особливо з ровесниками. Стосунки з товаришами перебувають у центрі життя підлітка, багато в чому визначаючи решту аспектів його поведінки і діяльності.

Для підлітка важливо не просто бути разом з ровесниками, а посідати серед них становище, що задовольнятиме його. Для деяких це намагання може виражатися через бажання посісти у групі однолітків позицію лідера, для інших - бути визнаним, улюбленим товаришем, ще для інших - непорушним авторитетом у якійсь справі, але у будь-якому випадку є головним мотивом поведінки школярів у середніх класах. Саме невміння, неможливість досягти такого становища найчастіше $\epsilon$ причиною недисциплінованості, навіть правопорушень підлітків, що супроводжується конфліктністю підлітків до підліткових компаній.

Потяг дітей до взаємовідносин - природно зумовлене явище. Воно впливає на кожен аспект життєдіяльності особистості. Підлітки прагнуть до взаємин із ровесниками. Відбувається формування системи соціальних взаємовідносин. У підлітковому віці відбуваються кардинальні перетворення в різних сферах психіки, значним змінам піддається мотиваційна сфера, сфера потреб. Розходження між виникаючими потребами та обставинами життя, що обмежують їх реалізацію, $\epsilon$ характерним для кожної вікової кризи. Тільки в перехідному періоді виникають та оформлюються моральні переконання, актуалізується таке новоутворення, як самовизначення, що характеризується усвідомленням себе в якості члена суспільства і конкретизується в суспільній позиції. Саме в цьому віці існує можливість чинити педагогічний вплив, оскільки, внаслідок недостатнього морального досвіду дитини моральні переконання знаходяться в нестійкому стані (Реана, 2007, с.278).

Як підкреслює Д. Фельдштейн, соціальне становлення людини, структурування іiі самопізнання й самовизначення як активно діючого суб'єкта визначається трансформацією позиції «Я стосовно суспільства» на дві позиції, що йдуть на зміну одна одній: «Я в суспільстві» та «Я і суспільство». У цьому періоді вчений виділяє три неоднорідні стадії: 10-11 років, коли загострена потреба у визнанні дорослими; 12-13 років, яка характеризується потребою в суспільному визнанні, в соціальному схваленні корисної діяльності, що висловлюється у мовній формі «я теж маю право, я можу, я повинен»; 14-15 років, коли домінує готовність проявити себе, застосувати свої сили (Фельдштейн, 1995, с. 127).

Підліток наслідує ідеал, недооцінюючи теперішнє, він спрямований у майбутнє. У процесі розвитку самопізнання, яке здійснюється на основі рефлексії, дитина формує образ Я, співвідносить «Я» реальне та ідеальне. Об'єктивна необхідність формування поглядів і суб'єктивне усвідомлення своїх можливостей викликає у підлітка інше ставлення до певної діяльності (Філоненко, 2008, с. 78).

Підлітки одночасно належать до багатьох соціальних груп. У них вони формуються, розвиваються, спілкуються і взаємодіють з іншими. У груповій взаємодії відбуваються становлення та самореалізація особистості підлітка, можливість проявити активну позицію. У таких умовах для кожного підлітка виникає неповторна ситуація спілкування та міжособистісних відносин, кожний займає певну життєву позицію. Життєва позиція формує те, про що підлітки думають, що відчувають, 
роблять, на що сподіваються і чого уникають. Сім'я, шкільні товариші мають велике значення - як пізнавальні, емоційні та поведінкові регулятори.

Проте існує криза підліткового віку, яка $\epsilon$ складною та довготривалою, i характеризується виникненням здатності ставити мету, розраховану на перспективу, що виходить за межі сьогодення. Вона полягає в тому, що більшість підлітків, володіючи достатньою мірою інтелектуальними уміннями та навичками навчальної діяльності, мають низьку стійкість саморегуляції: підліток часто визначає мету, але не доводить справу до логічного завершення (Реана, 2007).

Для визначення загальної структури міжособистісних відносин та статусу окремої дитини використовується соціометричні методики, методи дослідження соціальних зв'язків та ін.

Соціальний статус може розглядатися як реальне положення підлітка у колективі ровесників. Розрізняють такі види статусу: «зірка», «прийнятий», «неприйнятий», «ізольований» (Овчарова, 2001).

Дослідження міжособистісних відносин підлітків серед однолітків можливе за допомогою методики «Дослідження соціальних мереж підлітка». У результаті дослідження соціальний педагог отримує повне уявлення про характер взаємовідносин підлітка 3 оточуючими. Підлітки прагнуть до взаємин із ровесниками. Стосунки 3 товаришами перебувають у центрі життя підлітка, багато в чому визначаючи решту аспектів його поведінки і діяльності.

Для підлітка важливо не просто бути разом з ровесниками, а посідати серед них становище, що задовольнятиме його. Для деяких це намагання може виражатися через бажання посісти серед однолітків позицію лідера, для інших - бути визнаним, улюбленим товаришем, ще для інших - непорушним авторитетом у якійсь справі, але у будь-якому випадку $є$ головним мотивом поведінки школярів. Саме невміння, неможливість досягти такого становища найчастіше $\epsilon$ причиною недисциплінованості, навіть правопорушень підлітків, що супроводжується конфліктністю підлітків до підліткових компаній (Донцов, 2003, с. 112).

Досліджуючи міжособистісні стосунки, найбільш важливим показником є рівень конфліктності та її специфічні риси. Зокрема, Л. Петровська розглядає чотири основні групи понять, важливих для соціально-психологічного аналізу конфлікту: структура конфлікту, його динаміка, функції та класифікація (Петровская, 1997).

У структурі конфлікту можна виділити такі основні поняття: учасники конфлікту, умови перебігу конфлікту, образи конфліктної ситуації, можливі дії учасників конфлікту, наслідки конфліктних дій. Розгляд динаміки конфлікту являє собою розподіл його на певні стадії: виникнення об'єктивної конфліктної ситуації, усвідомлення іiї, здійснення конфліктної поведінки, розв'язання конфлікту. Функціональний аспект конфлікту зумовлений потребою змін у людських стосунках. Так, конфлікт $є$ протиборством, зіткненням протилежних тенденцій, оцінок, принципів, еталонів поведінки щодо предмета конфлікту. Конфлікт ображає прагнення затвердити принцип, учинок, ідею, самоствердитися. У міжособистісних взаєминах конфлікт $\epsilon$ деструкцією цих стосунків на емоційному, пізнавальному та поведінковому рівнях.

Більш глибшому розумінню конфліктів сприяє їх класифікація, що має спиратися на соціально-психологічні ознаки. Класифікація конфліктів відіграє важливу роль у розв'язанні конфліктних ситуацій. Адже ми знаємо, що тільки при умові правильно встановленого діагнозу можливе ефективне лікування. Дж. Г. Скот пропонує при проведенні дослідження конфлікту класифікувати його за такими ознаками: за джерелом, за змістом, за значущістю, за типами вирішення, за формами вияву, за типом структури взаємин, за соціально-психологічним ефектом, за соціальними результатами (Скот, 1991, с. 117).

Вчені К. Томас та Р. Кілмен визначають п'ять основних стилів поведінки у конфліктних ситуаціях, що грунтуються на власному стилі, стиль інших учасників 
конфлікту, а також на тип самого конфлікту: стиль конкуренції, ухилення, пристосування, компромісу, співпраці. Стиль поведінки в кожному конкретному конфлікті визначається ступенем прагнення задовольнити власні інтереси (діючи активно чи пасивно) та інтереси протилежної сторони учасників конфлікту (діючи спільно або індивідуально) (Трофімов, 1999).

Важливо зрозуміти, що кожен 3 названих стилів ефективний тільки за певних умов. Треба вміти адекватно використовувати будь-який 3 виокремлених стилів і робити свідомий вибір, ураховуючи конкретні обставини. Найкращий підхід визначається конкретною ситуацією.

Підлітки можуть переживати конфлікти на будь-якій стадії свого розвитку. Зменшення, вирішення, усунення, розв'язання конфліктних ситуацій дозволить забезпечити успіх у досягненні мети, краще зрозуміти інших.

Висновки і перспективи подальших розвідок. Отже, ми визначили основні характеристики міжособистісних відносин підлітків. На відносини впливають різні чинники: вікові особливості, характер спілкування, неформальні об'єднання, навколишнє середовище та інше.

Виховання підростаючого покоління наразі має бути орієнтоване на розвиток соціальності особистості, складовими якої $є$ активність, мобільність, зрілість, оскільки в сучасних умовах вже не можна обмежитися лише засвоєнням людиною суспільно визнаних норм і правил та досвіду.

Як підсумок, знання про вікові особливості, характер спілкування у групі однолітків та застосування зазначених діагностичних методик допоможе соціальному педагогу скласти уявлення про особливості міжособистісних відносин, визначити труднощі у спілкуванні дітей із сімей вимушених переселенців, розвивати та підтримувати їх.

\section{СПИСОК ВИКОРИСТАНИХ ДЖЕРЕЛ}

Трофімов, Ю., Рибалка, В., Гончарук, П. та ін. (1999). Психологія. Київ: Либідь. $558 \mathrm{c}$.

Юсупов, И. (1991). Психология взаимопонимания. Казань. 192 с.

Енциклопедія освіти. (2008). Кремень, В. (Ред). К.: Хрінком Інтер. 1040 с.

Реана, А. (2007). Психология подростка. Полное руководство. Санкт-Петербург: Прайм-ЕВРОЗНАК. 512 с.

Фельдштейн, Д. (1995). Проблемы возрастной и педагогической психологии. Москва 346 с.

Філоненко, М. (2008). Психологія спілкування: Навчальний посібник. Київ: Центр учбової літератури. 224 с.

Овчарова, Р. (2001). Справочная книга сочиильного педагога. Москва: ТЦ «Сфера». $480 \mathrm{c}$.

Донцов, А. О понятии группы в социальной психологии. (2003). Социальная психология: Хрестоматия. Белинская, Е., Тихомандрицкая, О. (Ред). Москва. 456 с.

Петровская, Л. (1997). О понятийной схеме социально-психологического анализа конфликта. Теоретические и методологические проблемы социальной психологии. Андреевой, Г., Богомоловой, Н. (Ред). Москва. 267 с.

Скот, Дж. Г. (1991). Конфликты и пути их преодоления. Київ 210 с.

\section{REFERENCES}

Trofimov, Yu., Rybalka, V., Honcharuk, P. \& in. (1999). Psykholohiia [Psychology]. Kyiv: Lybid. 558 s. (in Ukrainian)

Yusupov, I. (1991). Psikhologiya vzaimoponimaniya [Psychology of Understanding]. Kazan. 192 s. (in Russian)

Entsyklopediia osvity [Encyclopedia of Education]. (2008). Kremen, V. [Red]. Kyiv: Khrinkom Inter. 1040 s. (in Ukrainian) 
Reana, A. (2007). Psylhologiya podrostka. Polnoye rukovodstvo [Psychology of a Teenager. Complete Quide]. Sankt-Peterburg: Prajm-EVROZNAK. 512 s. (in Russian)

Feldshteyn, D. (1995). Problemy vozrastnoy i pedagogicheskoy psikhologi [Problems of Age and Pedagogical Psychology]. Moskva. 346 s. (in Russian)

Filonenko, M. (2008). Psikhologiia spilkuvannia: navchalnyi posibnyk [Psychology of Communication: tutorial]. Kyiv: Centr uchbovoii literatury. 224 s. (in Ukrainian)

Ovcharova, R. (2001). Spravochnaya kniga sotsialnogo pedagoga [Social Teacher's Reference Book]. Moskva: TTs "Sfera". 480 s. (in Russian)

Dontsov, A. O ponyatiyi gruppy v sotsialnoy psikhologii [On the Concept of a Group in Social Psychology]. (2003). Sotsialnaya psikhologiya: Khrestomatiya. Belinskaya, E., Tikhomandritskaya, O. (Red). Moskva. 456 s. (in Russian)

Petrovskaya, L. (1997). O ponyatiynoy skheme sotsialno-psikhologicheskogo analiza konflikta [On the Conceptual Scheme of Socio-psychological Analysis of the Conflict]. Teoreticheskiye $i$ metodologicheskiye problemy sotsialnoy psikhologii. Andreyevoy, G., Bogomolovoy, N. (Red). Moskva. 267 s. (in Russian)

Skot, Dzh. G. (1991). Konflikty i puti ikh preodoleniya [Conflicts and Ways to Overcome Them]. Kyiv. 210 s. (in Russian)

\title{
PSYCHOLOGICAL-PEDAGOGICAL METHODS OF INVESTIGATION OF CHILDREN FROM INTERNALLY DISPLACED FAMILIES: INTERPERSONAL RELATIONSHIPS STUDY
}

\author{
Nataliia Serhieieva \\ Candidate of Pedagogical Sciences, \\ Senior Scientist of Institute of Problems of \\ Education of the NAPS of Ukraine, \\ Kyiv, Ukraine \\ ORCID: 0000-0001-8153-2911, \\ e-mail: sergeeva.nataliya.v@gmail.com
}

\begin{abstract}
The article is devoted to the preparation of social teachers to study the interpersonal relationships of children from internally displaced families. The essence and content of the conceptual apparatus are revealed. The term of "interpersonal relationships" is characterized. It is specified that interpersonal relationships cover a wide range of phenomena, which have the attractiveness of one person to another as the main regulator of the uniqueness of interpersonal relations. The classification of interpersonal relationships based on several criteria, such as depth of relations, selectivity of partners, functions of relations, is described. Psychological determinant formations of interpersonal relations, characteristics and socio-psychological features of communication of children from internally displaced families, crisis periods of adolescence are analyzed. The aim of the article is to prepare social teachers for the study of interpersonal relations of children from internally displaced families, the disclosure of the features of their diagnosis. The main tasks and methods of diagnostics of interpersonal relationships are defined. It is noted that in the study of interpersonal relations the most important indicator is the level of conflictness and its specific features. Adaptive mechanisms of adolescence have been characterized. The main characteristics and socio-psychological features of the adolescence crisis have been revealed.

The study and analysis of the literature on the research problem allowed to investigate the interpersonal relationships diagnosis features from the point of view of socio-pedagogical science.
\end{abstract}

Keywords: internally displaced persons, crisis of adolescence, interpersonal relationships, adolescents, psycho-pedagogical methods, communication.

Стаття надійшла до редакиії 09.10.2019 p. 